\title{
IMPLEMENTASI PERMENDIKBUD NO. 14 TAHUN 2018 TERHADAP PENERIMAN PESERTA DIDIK BARU BERDASARKAN ZONASI SEKOLAH
}

\author{
Ni Komang Rai Widhyaningsih, I Wayan Arthanaya, Luh Putu Suryani \\ Fakultas Hukum Universitas Warmadewa, Denpasar - Bali, Indonesia
}

\begin{abstract}
Abstrak
Pendidikan ialah sesuatu yang penting serta bisa memberikan pengetahuan yang sanggup meningkatkan karakteristik hidup, baik pada kehidupan pribadi, kehidupaan masyarakat, ataupun kehidupan bernegara. Penerimaan Peserta Didik Baru yang sering disebut PPDB ialah kegiatan tiap tahun yang merupakan tahap seleksi bagi calon peserta didik baru yang diselenggarakan oleh panitia tingkat sekolah di bawah pengawasan dan koordinasi Dinas Pendidikan. PPDB pada tahun ini menggunakan sistem baru yaitu sistem zonasi yang dimana sistem ini bertujuan untuk pemerataan siswa. Tujuan dari penelitian ini adalah untuk mendeskripsikan bagimana implementasi Permendikbud nomor 14 tahun 2018 dan apa faktor-faktor penghambat pelaksanaan Permendikbud nomor 14 tahun 2018 terhadap penerimaan siswa baru berdasarkan zonasi. Penelitian ini didesain dengan menggunakan pendekatan penelitian hukum empiris. Hasil penelitian ini menunjukkan bahwa implementasi Permendikbud Nomor 14 Tahun 2018 pada Sekolah Menengah Atas/Kejuran khususnya di wilayah Kuta Selatan belum berjalan secara efektif karena ada salah satu sekolah yang menerima protes dari orang tua peserta didik yang mengakibatkan proses penerimaan peserta didik baru terhambat. Selain itu, penelitian ini juga menunjukkan bahwa faktor-faktor penghambat pelaksanaan Permendikbud Nomor 14 Tahun 2018 terhadap penerimaan siswa baru berdasarkan zonasi terdiri dari faktor internal, yaitu panitia kurang selektif dalam memeriksa persyaratan siswa dan aplikasi yang disediakan mengalami gangguan, dan faktor eksternal yaitu lokasi, mainset masyarakat, dan surat keterangan domisili.
\end{abstract}

Kata Kunci: Pendidikan, Peserta Didik, Sistem Zonasi

\begin{abstract}
Education is something that is important can provide knowledge that can improve the characteristics of life, both in personal life, community life, and state life. A New Student Admission, often referred to as PPDB, is an annual activity which is the selection stages for prospective new students organized by school-level committees under the supervision and coordination of the Office of Education. This year, PPDB uses a new system, the zoning system, which aims to equalize students. The purpose of this study was to describe how the implementation of Permendikbud number 14 in 2018 and what are the factors inhibiting the implementation of Permendikbud number 14 in 2018 on the admission of new students based on zoning. This research was designed using an empirical legal research approach. The results of this study indicated that the implementation of Permendikbud No. 14 of 2018 in High Schools / Kejuraan especially in the South Kuta area has not been running effectively because there was one school that received protests from students' parents which resulted in the process of hiring new students being hindered. In addition, this study also showed that the inhibiting factors for the implementation of Permendikbud No. 14 of 2018 on the admission of new students based on zoning consisted of internal factors, namely the committee was less selective in examining student requirements and the application provided was experiencing interference, and external factors namely location, community mainset, and domicile certificate.
\end{abstract}

Keywords: Education, Students, Zoning System

\section{PENDAHULUAN}

Pendidikan adalah suatu hal yang sangat penting bagi setiap individu. Pendidikan bisa memberikan pengetahuan yang dapat meningkatkan karakteristik hidup, baik pada kehidupan pribadi, kehidupaan bermasyarakat, ataupun kehidupan bernegara. Hampir seluruh negara di dunia menyadari bahwa pendidikan dapat membantu menyediakan serta membentuk sumber daya manusia (SDM) yang sangat berkualitas. 
Sadar akan pentingnya pendidikan, setiap orang berlomba-lomba untuk mendapatkan pendidikan yang terbaik agar dapat menjadi SDM yang berkualitas, serta dapat bersaing di kalangan Internasional (Erhamwilda, 2004; Muhardi, 2004; Ningrum, 2016). Demi menciptakan SDM yang berkualitas pemerintah memiliki kewajiban untuk menyelenggarakan proses belajar mengajar dengan baik dan benar. Penerimaan Peserta Didik Baru yang sering dikatatakan PPDB merupakan kegiatan rutin setiap tahun dimana ini adalah tahap seleksi bagi calon peserta didik baru yang diselenggarakan oleh panitia tingkat sekolah di tangan pengawasan serta koordinasi Dinas Pendidikan. Awalnya sistem penerimaan peserta didik baru dibuat berdasarkan atas hasil Nilai Ujian Nasional (NUN).

Setiap sekolah akan menentukan berapa NUN terkecil yang dapat terdaftar dalam sekolah itu, biasanya sekolah terfavorit akan membuat batas NUN yang lumayan tinggi, serta sekolah-sekolah lainnya akan membuat batas NUN di bawah dari batas NUN sekolah favorit. Namun tahun ini sistem penerimaan peserta didik baru dirubah. Tahun ajaran 2019/2020 sistem penerimaan peserta didik baru mengenakan sistem zonasi seperti yang tetapkan pada Permendikbud no. 14 tahun 2018. Sistem zonasi ini mewajibkan sekolah yang diselenggarakan oleh pemerintah daerah ataupun yang sering disebut yaitu Sekolah Negeri wajib menerima siswa yang radius atau jarak tempuh dari rumah ke sekolah dekat. Siswa yang bukan berasal dari lokasi zonasi tersebut minimal harus berdomisili selama 6 Bulan.

Berdasarkan uraian latar belakang di atas, penelitian ini didesain dengan tujuan mendeskripsikan bagaimana implementasi Permendikbud nomor 14 tahun 2018 dan apa faktor-faktor penghambat pelaksanaan Permendikbud nomor 14 tahun 2018 terhadap penerimaan siswa baru berdasarkan zonasi.

\section{METODE PENELITIAN}

Penelitian ini memakai metode hukum empiris dimana suatu metode penelitian hukum menggunakan fakta empiris yang diambil dari tingkah laku manusia baik verbal yang didapat dari wawancara maupun tindakan nyata atau secara langsung dan pengamatan langsung. Penelitian ini juga dipakai untuk mengamati hasil dari tinggah laku seseorang yang berupa peninggalan fisik maupun arsip (Fajar \& Achmad, 2010). Pendekatan masalah yang digunakan yaitu pendekatan sosiologis. pendekatan ini mengacu pada peraturan-peraturan tertulis untuk kemudian dilihat bagaimana implementasinya di lapangan.

Sumber bahan hukum yang dipakai pada penelitian adalah bahan hukum primer dan sekunder. Data primer adalah data yang didapat langsung dari masyarakat sebagai sumber pertama melalui penelitaan lapangan yang dilakukan melaui wawancara (Waluyo, 1996). Sumber data sekunder ialah pengumpulan data yang diperoleh dari berbagai kepustakaan seperti buku-buku referensi, jurnal hukum, dan yang lain terkait dalam permasalahan. Data yang sudah terkumpul dianalisis menggunakan metode analisis kualitatif. Selanjutnya, hasil penelitian disajikan secara deskriptif menggunakan metode informal.

\section{HASIL PENELITIAN DAN PEMBAHASAN}

\section{Implementasi dari Permendikbud No. 14 Tahun 2018}

Guntur Setiawan berpandangan bahwa implementasi merupakan perluasan aktivitas dengan tindakan yang menyesuaikan proses agar tercapai tujuannya serta diperlukan jaringan pelaksana pelayanan yang baik (Setiawan, 2014). Pengertian tersebut dapat diartikan bahwa implementasi ialah suatu proses untuk melaksanakan ide ataupun sesuatu aktivitas baru dengan harapan seseorang mampu memperoleh dan melaksanakan penyesuaian dalam tubuh birokrasi demi terciptanya suatu tujuan yang dapat dicapai dengan jaringan pelaksana yang dipercaya.

Istilah implikasi sering kali digunakan tanpa tahu apa arti dan definisinya. Kata implikasi jarang dipakai pada percakapan di setiap harinya. Penggunaan kata implikasi lebih sering dipakai pada sebuah bahasa penelitian. Oleh sebab itu kajian yang membahas mengenai arti kata implikasi masih sedikit. Tetapi saat kita mendengar istilah implikasi hal yang terpikirkan biasanya adalah sebuah akibat atau suatu hal yang berdampak langsung (Hadiwardoyo, 2011).

Sistem zonasi dalam Permendikbud No. 51/2018 perubahan atas Permendikbud No.14/2018 dapat dijelaskan bahwa penerapan sistem zonasi mebuat calon peserta didik harus belajar di sekolah yang memiliki jarak paling dekat dari rumahnya. Dari banyaknya persoalan pendidikan di Indonesia yang paling sering terjadi ialah pemerataan. Sekolah unggulan cuma ada di kota besar. Yang 
mengakibatkan kesenjangan pendidikan. Sekolah favorit akan terus disenangi, terkenal, maju, unggul dan tentunya mahal. Sedangkan sekolah di desa akan selalu jelek, terbelakang, tidak mapan secara sarana dan prasarana karena fasilitas itu lambat laun akan rusak, dan tidak mampu menggantinya. Dengan begitu seiring berjalannya waktu sekolah tersebut akan ditinggalkan oleh siswanya (Arfan, 2019).

Dengan sistem seperti itu, tidak akan ada sekolah yang kelebihan siswa. Juga tidak akan ada sekolah yang tidak memiliki siswa. Pembagian siswa menjadi sama antar daerah maupun kota. Dengan mendapatkan siswa yang cukup setiap tahunnya lambat laun sekolah non- favorit akan berubah menjadi sekolah favorit serta memiliki fasilitas yang bagus sehingga cerita sekolah yang kehabisan murid, atau memberhentikan guru karena tidak memiliki siswa tidak ada ada lagi. Begitu pun sebaliknya sekolah unggulan tidak akan terus menjadi sekolah terbaik karena kini siswa terbatasi dengan zonasi. Jumlah siswanya tidak akan berlebih dan tidak akan kekurangan. Selain meratakan jumlah siswa pada tiap-tiap sekolah, juga mampu mengurangi angka kemacetan di kota karena sistem penerimaan siswa menggunakan zona terdekat dari rumah.

Dengan kebijakan ini, pemerintah juga berupaya agar terpenuhinya kewajibannya serta mewujudkan akses pendidikan yang merata di setiap wilayah. Zonasi sekolah mempersembahkan harapan baru bagi kelompok siswa yang selama ini tidak memiliki peluang untuk bersekolah di "sekolah mahal". Sekarang mereka dapat menekan biaya sekolah karena dapat bersekolah di sekolah terdekat dengan tempat tinggalnya, meskipun mereka tidak memilik pretasi akademik yang bagus. Selain itu, mereka dapat menghemat biaya transportasi, sehingga secara tidak langsung zonasi juga dapat mengurangi kemacetan di beberapa wilayah. Siswa juga tidak perlu berebut naik angkutan umum untuk pergi ke sekolah (Hadiwardoyo, 2011).

Berdasarkan hasil wawancara dengan Bapak I Ketut Suwita S.Pd., M.Pd., Ketua Panitia PPDB SMAN 1 Kuta Selatan mengatakan, "Sesungguhnya konsep ini baik, cuma anak- anak yang pingin. Dari persepsi anak-anak saja 'saya pingin masuk kesana tapi saya tidak bisa karna terganjal oleh zona'. Contohnya si A ingin berprestasi dan tidak ingin disana tidak bisa." Dari penjelasan diatas dapat diketahui bahwa implikasi dari penerapan sistem zonasi pada SMAN 1 Kuta Selatan membuat anak-anak yang ingin bersekolah dan berprestasi disana menjadi tidak bisa karena terhalang oleh zona atau jarak rumah mereka. I Ketut Suwita juga mengatakan, "Penerimaannya dengan sistem antrian online sehingga tidak berjubel. Disana juga sudah berisi kapan dan jam berapa dia harus datang, apabila datang tidak sesuai dengan antrian ya tidak akan dilayani. Karena peminatnya banyak, jadi berlangsung selama 2 minggu."

Mengenai implikasi dari penerapan Permendikbud No. 14 Tahun 2018 I Ketut Suwita berpendapat bahwa dengan diterapkannya sistem baru dalam penerimaan peserta didik baru ini mengakibatkan menurunnya tingkat belajar siswa. Beliau mengatakan, "Tingkat belajar siswa dengan sistem zonasi kongnitifnya lebih baik yang dulu, karna yang nemnya lebih kecil akan tersingkir. Yang dapat itukan yang nemnya besar, ranking nya besar. Apalagi kan ada prioritas prestasi akademik akan lebih mudah masuk. Gregetnya sekarang lebih rendah karna semuanya kan rata, semua sekolah seperti itu. Mungkin ada beberapa yang pintar yang lainnya ada yang bawah, tapi kebanyakan rata-rata."

Sedangkan wawancara di SMAN 2 Kuta Selatan yang merupakan sekolah menengah atas terbaru di Badung ini dengan Dr. I Nyoman Tingkat, Spd, M.Hum selaku Kepala Sekolah sekaligus Ketua PPDB SMAN 2 Kuta Selatan mengatakan, "Sistem zonasi dengan yang sebelumnya sebenarnya sama saja cuma sistem zonasi itukan filosofinya lebih mendekatkan peserta didik dengan sekolah dan pemerataan pendidikan. Pemerataan tidak hanya dalam arti kuantitas tapi juga pemeratan dalam arti kualitas, sehingga tidak ada kastanisasi sekolah atau sekolah favorit maupun sekolah non favorit jadi posisi sekolah itu sama walaupun dibalik semua itu pasti ada sisi-sisi negatifnya. Contohnya seorang siswa dari Nusa dua ingin bersekolah di SMAN 1 Denpasar karna zonasi jdi tidak bisa. Walaupun dia ngebet ingin bersekolah di Denpasar. Sejumlah siswa juga tidak ingin punya teman dari SD, SMP, SMA itu-itu saja."

Berbeda halnya dengan hasil wawancara pada SMKN 1 Kuta Selatan yang telah menggunakan atau menerapan sistem zonasi ini sebanyak 2 kali. Bapak Putu Budiasa mengatakan, "Yang tahun ini efektif, kalo yang pertama kali itu sampai ribut-ribut karena sistemnya baru jadi orang tua siswa itu kaget, dan menimbulkan pro dan kontra karena terbiasa dengan sistem yang lama. Tapi kita disini juga menggunakan sistem NEM tertinggi dan juga prestasi. Yang tahun ini aman tidak ada 
protesprotes seperti tahun sebelumnya, karena kan sudah pernah diberlakukan dan juga kami disini 1 (satu) minggu sebelum mulai pendaftaran diadakan sosialisasi dulu."

Dari seluruh hasil wawancara di atas, yang menjadi implikasi dari penerapan sistem zonasi ini ialah siswa-siswa yang ingin bersekolah di tempat yang diinginkan dan berprestasi di sekolah Negeri yang diinginkan tidak bisa karena terhalang oleh zona yang ada, dan sistem ini juga membuat siswa memiliki teman yang sama sedari SD, SMP, hingga SMA. Karena zonasi sekolah dengan rumahnya yang dekat.

Jadi dilihat dari semua pembahasan di atas, Implementasi Permendikbud Nomor 14 Tahun 2018 pada Sekolah Menengah Atas/Kejuran khususnya di wilayah Kuta Selatan belum berjalan secara efektif. Karena ada salah satu sekolah yang menerima protes dari orang tua peserta didik yang mengakibatkan proses penerimaan peserta didik baru terhambat, dimana proses penerimaan itu seharusnya berlangsung selama 1 minggu. Tetapi karena menerima berbagai protes dari orang tua siswa dan wali murid mengakibatkan proses penerimaan peserta didik baru disekolah tersebut berlangsung selama 2 minggu.

\section{Faktor-faktor penghambat penerapan Permendikbud No. 14 tahun 2018}

Faktor-faktor penghambat dalam suatu penerapan pereraturan berkaitan dengan efektivitas berlakunya hukum tersebut. Kata efektif berasal dari bahasa Inggris yaitu efektif yang memiliki arti keberhasil atau sesuatu yang dilakukan berhasil dengan baik. Kamus ilmiah popular mengartikan efetivitas sebagai ketepatan penggunaan hasil guna atau menunjang tujuan. Menurut Kamus Besar Bahasa Indonesia efektif adalah sesuatu yang ada efeknya (akibatnya pengaruhnya kesannya) dimulai saat berlakunya suatu Undang-Undang atau peraturan. Kata efektivitas sendiri berasal dari kata efektif yang berarti efek atau akibat yang diinginkan pada sebuah tindakan. Semua kegiatan yang efisien berarti efektif karena berdasarkan hasil tujuan yang hendak dicapai dari tindakan itu. Pada dasarnya efektivitas adalah tingkat keberhasilan dalam mencapaian tujuan. Efektivitas merupakan pengukuran tercapainya sasaran yang telah ditentukan sebelumnya.

Efektivikasi hukum adalah suatu proses yang bertujuan supaya hukum berlaku serta berjalan dengan baik. Jika ingin tahu sejauh mana efektivitas dari suatu hukum itu, kita harus dapat mengukur sejauh mana hukum itu dipatuhi oleh sebagian besar sasarannya barulah dapat dikatakan bahwa aturan hukum tersebut adalah efektif. Walaupun dikatakan aturan yang ditaati itu efektif masih dapat dipertanyakan lebih jauh derajat efektivitasnya karena seorang menaati maupun tidak suatu aturan hukum bergantung dengan kepentingan dirinya sendiri. Keberhasilan hukum apabila norma hukum tersebut ditaati serta dilaksankan rakyat mampu maupun penegakkan hukum pelaksanaan hukum dikatakan efektif dan berhasil dalam penerapannya. Kegagalan pelaksanaan hukum ialah ketentuan hukum tidak tercapai tujuannya atau tidak berhasil dalam penerapannya. Faktor-faktor pengaruhi dalam suatu hal bisa menyebabkan atau memberi pengaruhi di dalam pelaksanaan dan menerapan hukum tersebut. Faktor yang mempengaruhi dapat dikaji dari beberapa hal yaitu keberhasilannya dan kegagalannya.

Faktor keberhasilan dipengaruhi oleh beberapa hal meliputi substansi hukum struktur kultur dan fasilitasnya. Norma hukum bisa dibilang berhasil apabila ditaati dan dilaksanakan oleh rakyat maupun penegak hukum itu sendiri. Sedangkan faktor kegagalan dalam menjalankan hukum adalah karena ketidakjelasan suatu norma atau norma hukum tersebut kabur bisa juga karena aparatur penegak hukumnya yang korup maupun rakyatnya tidak sadar dan tidak taat pada hukum atau fasilitas pendukung dalam melaksanakan hukum itu sangat sedikit.

Suatu hukum memiliki derajat efektivitas yang ditentukan berdasarkan taraf kepatuhan rakyat atau individu terhadap hukum termasuk penegak hukum (Hermawan Usman, 2014; Novita, Prasetyo, \& Suparno, 2017; Rosana, 2014). Maka diasumsikan bahwa tingkat kepatuhan hukum tertinggi ialah sebuah bukti bahwa sistem hukum tersebut telah berfungsi. Difungsikannya hukum membuat pertanda hukum sudah mencapai tujuan hukum yaitu berusaha mempertahankan serta melindungi rakyat dalam perkembangannya. Dalam penerapannya terdapat beberapa faktor penghambat yaitu faktor penghambat internal dan faktor penghambat eksternal. Ada beberapa faktor pengambat internal penerapan Permendikbud No.14 Tahun 2018 anatar lain:

1. Panitia pelaksana proses Penerimaan Peserta Didik Baru tidak selektif dalam memeriksa berkasberkas persyaratan calon peserta didik baru sehingga mereka dapat dengan mudah memalsukannya. 
2. Aplikasi yang disediakan untuk pendaftaran online mengalami gangguan serta jaringan kurang memadai.

3. Kurangnya sosialisasi tentang penerapan sistem penerimaan peserta didik baru berdasarkan zonasi.

4. Kurangnya pemerataan saran dan prasarana anatara sekolah favorit dan sekolah non favorit.

5. Saran dan prasana antara lain yaitu :

1. Sekolah : jumlah sekolah negeri yang ada di Kuta Selatan terlalu sedikit, sedangkan jumlah calon peserta didik baru cukup banyak. Sehingga membuat siswa yang tidak mendapat sekolah negeri bersekolah di sekolah swasta.

2. Transportasi : tidak adanya transportasi umum ataupun bus sekolah yang bertugas menjemput dan mengantarkan siswa ke sekolah sehinga sering menyebabkan kemacetan.

Faktor-faktor penghambat extrenal dalam pelaksanaan Permendikbud ini antara lain :

1. Lokasi: Yang menjadi faktor penghambat itu konsentrasi jumlah penduduk di Kuta selatan yang terlalu padat, tidak sebanding dengan jumlah sekolah yang ada.

2. Mainset masyarakat yang masih lekat dengan istilah sekolah favorit dapat memberikan pendidikan serta fasilitas terbaik. Dan apabila tidak bersekolah di sekolah negeri maupun sekolah favorit itu tidak bagus atau anaknya akan dinilai bodoh.

3. Kartu tanda domisili yang diterbitkan minimal 6 bulan.

\section{SIMPULAN DAN SARAN}

1. Simpulan

Berdasarkan uraian di atas, beberapa simpulan dapat dibuat, yaitu: pertama, implementasi Permendikbud Nomor 14 Tahun 2018 pada Sekolah Menengah Atas/Kejuran khususnya di wilayah Kuta Selatan belum berjalan secara efektif karena ada salah satu sekolah yang menerima protes dari orang tua peserta didik yang mengakibatkan proses penerimaan peserta didik baru terhambat, dimana proses penerimaan itu seharusnya berlangsung selama 1 minggu. Tetapi karena menerima berbagai protes dari orang tua siswa dan wali murid mengakibatkan proses penerimaan peserta didik baru disekolah tersebut berlangsung selama 2 minggu. Kedua, faktor-faktor penghambat pelaksanaan Permendikbud Nomor 14 Tahun 2018 terhadap penerimaan siswa baru berdasarkan zonasi, yaitu dilihat dari faktor internal dan faktor eksternal. Faktor internal yang disebutkan dalam penghambat pelaksanaan penerimaan siswa baru berdasarkan zonasi yaitu panitia kurang selektif dalam memeriksa persyaratan siswa, aplikasi yang disediakan mengalami gangguan, kurangnya sosialisasi serta kurangnya sarana, dan prasarana. Selain itu, faktor eksternal yang menjadi penghambat dalam penerimaan siswa baru berdasarkan zonasi yaitu: lokasi, mainset masyarakat, dan surat keterangan domisili.

\section{Saran}

Berdasarkan simpulan tersebut di atas, ada beberapa saran yang perlu disampaikan kepada pihak terkait, yaitu: pertama, bagi pemerintah, Permendikbud Nomor 14 Tahun 2018 ini belum sepenuhnya berjalan dengan efektif. Oleh karena itu, pemerintah hendaknya mengkaji lebih dalam mengenai peratuan tentang penerimaan peserta didik baru berdasarkan zonasi sekolah, sehingga tidak terjadinya kekaburan norma serta peraturan tersebut dapat dilaksanakan dengan efektif agar segala sesuatu bentuk tindakan yang menyimpang tidak terjadi lagi. Dan kedua, bagi masyarakat, Indonesia merupakan negara hukum, setiap warga negara harus taat dan patuh terhatap aturan hukum yang berlaku. Orang tua siswa maupun wali siswa harusnya tidak memaksakan kehendaknya yang dapat mengakibatkan pelanggaran hukum. Sebaiknya orang tua siswa dan masyarakat setempat mematuhi aturana yang sudah ditetapkan dalam Permendikbud No. 14 Tahun 2018 mengenai penerimaan peserta didik baru berdarkan zonasi sekolah.

\section{DAFTAR PUSTAKA}

Arfan, M. M. (2019). Nalar Kritis Pendidikan. Yogyakarta: Ircisod.

Erhamwilda. (2004). Mencermati Problem Pendidikan Indonesia Untuk Memperbaiki Kualitas Pendidikan (Suatu Upaya Meningkatkan Sdm Bangsa). Mimbar, XX(4), 457-477.

Fajar, M., \& Achmad, Y. (2010). Dualisme Penelitian Hukum Empiris \& Hukum Normatif. Jakarta: Pustaka Pelajar. 
Hadiwardoyo. (2011). Perkawinan menurut Islam dan Katolik Menurut Implikasi dalam Kawin Campur. Jakarta: Kanisius.

Hermawan Usman, A. (2014). Kesadaran Hukum Masyarakat Dan Pemerintah Sebagai Faktor Tegaknya Negara Hukum Di Indonesia. Jurnal Wawasan Yuridika, 30(1), 26-53.

Muhardi. (2004). Kontribusi Pendidikan dalam Meningkatkan Kualitas Bangsa Indonesia. Mimbar, XX(4), 478-492.

Ningrum, E. (2016). Pengembangan Sumber Daya Manusia Bidang Pendidikan. Jurnal Geografi Gea, 9(1).

Novita, R. A., Prasetyo, A. B., \& Suparno. (2017). Efektivitas Pelaksanaan Undang-Undang Nomor 2 Tahun 1960 Tentang Perjanjian bagi Hasi Tanah Pertanian (Tanah Kering) di Desa Bringin, Kecamatan Bayan, Kabupaten Purworejo. Dinopenegoro Law Journal, 6(2), 1-12.

Rosana, E. (2014). Kepatuhan Hukum Sebagai Wujud Kesadaran Hukum Masyarakat. Jurnal TAPIs, $10(1)$.

Setiawan, G. (2014). Impelemtasi dalam Birokrasi Pembangunan. Jakarta: Balai Pustaka.

Waluyo, B. (1996). Penelitian Hukum dalam Praktek. Jakarta: Sinar Grafika. 